\title{
Pillared titanates: titanium oxide of high surface area and porosity
}

\author{
Shi-Jane Tsai, Sung-Jeng Jong, Lin-Shu Du, Shung-Chung Liu and Soofin Cheng* \\ Department of Chemistry, National Taiwan University, Taipei 107, Taiwan
}

(Received 5 March 1993; accepted 10 September 1993)

\begin{abstract}
Pillaring layered titanates with robust polyoxometallic oligomers is a route to prepare microporous titanium oxide. In addition to using the organic intercalated compounds as precursors, the pillaring reaction on this layered metal oxide with a high charge density was facilitated by using layered titanate of low crystallinity and small particle size, which was achieved by hydrolyzing $\mathrm{TiCl}_{4}$ in strong alkaline solution. The resultant compound had a formula close to that of layered trititanate, $\mathrm{NaHTi}_{3} \mathrm{O}_{7} \cdot 2 \mathrm{H}_{2} \mathrm{O}$. Both aluminium Keggin ions, formulated as $\left[\mathrm{Al}_{13} \mathrm{O}_{4}(\mathrm{OH})_{24}\left(\mathrm{H}_{2} \mathrm{O}_{12}\right]^{7+}\right.$, and hydroxyzirconium tetramer cations, formulated as $\left[\mathrm{Zr}_{4}(\mathrm{OH})_{8}\left(\mathrm{H}_{2} \mathrm{O}\right)_{16}\right]^{8+}$, were introduced into the interlayers of this layered titanate. The layered structure was retained up to $600^{\circ} \mathrm{C}$ for the alumina-pillared derivative, but only to $500^{\circ} \mathrm{C}$ for the zirconia-pillared derivative. The pillared samples had BET surface areas $\geqslant 150 \mathrm{~m}^{2} / \mathrm{g}$ and contained both micro- and mesopores. Many of the physicochemical properties of the compounds before and after pillaring were compared. Most of the characteristic properties of $\mathrm{TiO}_{2}$ were retained on the pillared derivatives.
\end{abstract}

Keywords: pillaring; layered titanate; aluminium Keggin ions; hydroxyzirconium tetramer cations; titanium oxide

\section{Introduction}

Titanium oxide has several significant and distinctive properties as a catalyst or catalyst support. $\mathrm{TiO}_{2}$ is a typical photocatalyst and is responsible for a variety of organic reactions [1]. The strong metal-support interaction (SMSI) was first reported for noble metals supported on $\mathrm{TiO}_{2}$ [2]. Moreover, $\mathrm{TiO}_{2}$-based catalysts were found to be the best catalysts for the selective reduction of $\mathrm{NO}_{x}$ with $\mathrm{NH}_{3}$ [3] and for xylene oxidation to phthalic anhydride [4]. However, compared to $\mathrm{Al}_{2} \mathrm{O}_{3}$ and $\mathrm{SiO}_{2}, \mathrm{TiO}_{2}$ has a relatively low surface area. In order to obtain $\mathrm{TiO}_{2}$ of high surface area, Komiyama et al. [5] carried out chemical vapor deposition with $\mathrm{Ti}\left(\mathrm{C}_{3} \mathrm{H}_{7} \mathrm{O}\right)_{4}$ at $250^{\circ} \mathrm{C}$ in a $\mathrm{TiO}_{2}$ deposit reactor. $\mathrm{TiO}_{2}$ of amorphous and porous structure was formed, and its surface area reached a value of $300 \mathrm{~m}^{2} / \mathrm{g}$. However, the structure sint-

\footnotetext{
* Corresponding author.
}

ered, and the surface area decreased abruptly after heating at $300^{\circ} \mathrm{C}$ and shrinked to $11 \mathrm{~m}^{2} / \mathrm{g}$ at $390^{\circ} \mathrm{C}$.

The goal of this work was to pillar the layered compound of titanium oxide with aluminium Keggin ions and hydroxyzirconium cations so that the interior surfaces of the laminar metal oxide could be exposed for chemical or catalytic reactions.

The term "pillaring" designates the chemical process which introduces some guest molecules or ions in between the main sheets of lamellar compounds and therefore establishes free space between successive sheets. A pillaring reaction provides a new route to prepare microporous materials. The advantage of this process is that the structures and properties of the resultant assemblies can be mediated by controlling subtle guest-host interactions [6-8]. Among the available layered compounds, clays have received the most attention, and pillared clays seem to have great potential in the area of 
acid-catalyzed reactions, such as cracking and alkylation $[9,10]$. Recently, there were pronounced developments in the pillaring of other layered metal oxide compounds, such as $\mathrm{Li}_{x} \mathrm{MoO}_{3}$ [11], double hydroxides [12-14], metal phosphates $[15,16]$, buserite [17], as well as tetra- and trititanates $[18,19]$. Different from smectite clays, which are capable of swelling and expand in aqueous solution, metal oxides, which possess a high charge density on the framework, usually cannot react directly with inorganic oligomers in an aqueous solution. Instead, the organic ion-expanded lamellar compounds were often used as precursors to facilitate the exchange of polyoxo cations or anions into the interlayers. The aluminium Keggin ion with formula $\left[\mathrm{Al}_{13} \mathrm{O}_{4}(\mathrm{OH})_{24}\left(\mathrm{H}_{2} \mathrm{O}\right)_{12}\right]^{7+}$ (abbreviated as $\mathrm{Al}_{13}$ ) is a large polyoxo cation, which has been reported to be thermally stable at temperatures higher than $500^{\circ} \mathrm{C}$ [20]. Previously, we carried out a thorough study on the pillaring of tetratitanate, $\mathrm{K}_{2} \mathrm{Ti}_{4} \mathrm{O}_{9}$, with $\mathrm{Al}_{13}$ cations [18]. The layered titanate was prepared by a solid-state reaction and had a high crystallinity and a low surface area. The introduction of $\mathrm{Al}_{13}$ cations into the interlayers increased the surface area, e.g. from 13 to $c a .62 \mathrm{~m}^{2} / \mathrm{g}$; however, the pore volume was low. On the other hand, Anderson and Klinowski [19] prepared $\mathrm{Al}_{13}$-pillared trititanate by direct exchange of $\mathrm{Na}_{2} \mathrm{Ti}_{3} \mathrm{O}_{7}$ (also from a solid-state reaction) with $\mathrm{Al}_{13}$ cations. The product was shown to have a microporous structure and a BET surface area of $105 \mathrm{~m}^{2} / \mathrm{g}$. However, the ion exchange was not complete and peaks corresponding to the starting material, $\mathrm{Na}_{2} \mathrm{Ti}_{3} \mathrm{O}_{7}$, remained in its X-ray diffractogram. The significant contribution from this study is a new synthetic approach by using layered titanate of low crystallinity as the starting material. Using hexylamine as a pre-swelling agent, both $\mathrm{Al}_{13}$ and $\mathrm{Zr}_{4}$ (abbreviation of $\left.\left[\mathrm{Zr}_{4}(\mathrm{OH})_{8}\left(\mathrm{H}_{2} \mathrm{O}\right)_{16}\right]^{8+}\right)$ polycations could be introduced into the interlayers, resulting in the formation of porous structures. Although hydroxyzirconium tetramer cations, with the generally accepted formula $\left[\mathrm{Zr}_{4}(\mathrm{OH})_{8}\left(\mathrm{H}_{2} \mathrm{O}\right)_{16}\right]^{8+}$, were frequently used as pillaring species for clays [21], the introduction of $\mathbf{Z r}_{4}$ cations into highly crystalline $\mathrm{K}_{2} \mathrm{Ti}_{4} \mathrm{O}_{9}$ was unsuccessful owing to the high competition of protons in the $\mathrm{Zr}(\mathrm{IV})$ solution $(\mathrm{pH} \sim 1)$ for the ion-exchange sites. To the best of our knowledge, smectite clays have been the only layered materials reported up to now that can be pillared with $\mathrm{Zr}_{4}$ cations forming molecular sieve structures. In the present study, both $\mathrm{Al}_{13^{-}}$and $\mathrm{Zr}_{4}$-pillared titanates were prepared. The physicochemical properties of these pillared products were characterized. Their possible applications in catalysis are also discussed.

\section{Experimental}

\section{Reagents}

Reagent-grade chemicals were used without further purification. $\mathrm{TiCl}_{4}, \mathrm{TiO}_{2}$ (anatase) and $\mathrm{K}_{2} \mathrm{CO}_{3}$ were purchased from Merck. $\mathrm{AlCl}_{3} \cdot 6 \mathrm{H}_{2} \mathrm{O}$ and $n$ hexylamine were from Janssen, $\mathrm{HCl}$ from Riedelde Haen, and $\mathrm{ZrOCl}_{2} \cdot 8 \mathrm{H}_{2} \mathrm{O}$ from Nacalai Tesque.

\section{Synthesis of layered titanate}

$\mathrm{K}_{2} \mathrm{Ti}_{4} \mathrm{O}_{9}$ of high crystallinity was prepared by a solid-state reaction of a stoichiometric mixture of $\mathrm{TiO}_{2}$ and $\mathrm{K}_{2} \mathrm{CO}_{3}$ powder at $800^{\circ} \mathrm{C}$ for $20 \mathrm{~h}$. The product was identified by $\mathrm{X}$-ray powder diffraction. $\mathrm{TiOCl}_{2}$ solution was prepared by mixing equal weights of $\mathrm{TiCl}_{4}$ and $1.0 \mathrm{~N} \mathrm{HCl}$. Layered titanate of low crystallinity was synthesized by neutralization of the $\mathrm{TiOCl}_{2}$ solution with a strong alkaline solution, e.g., $\mathrm{NaOH}$, followed by hydrothermal treatment at $100^{\circ} \mathrm{C}$ for seven days. The $\mathrm{pH}$ of the solution was $c a$. 13. The structure of the resultant compound was examined by X-ray powder diffraction (XRD) and its composition was determined by inductively coupled plasma atomic emission spectrometry (ICP-AES) and thermogravimetric analysis (TGA).

\section{Preparation of polyoxo metal cation-pillared titanate}

The reaction pathways for preparing aluminium Keggin ion-pillared tetratitanate from $\mathrm{K}_{2} \mathrm{Ti}_{4} \mathrm{O}_{9}$ is described in ref. 18. $\mathrm{K}_{2} \mathrm{Ti}_{4} \mathrm{O}_{9}$ was converted to its proton form, formulated as $\mathrm{H}_{2} \mathrm{Ti}_{4} \mathrm{O}_{9}$, by stirring with $1 \mathrm{~N} \mathrm{HCl}$ overnight. Then, $n$-hexylammonium 
ion-expanded titanate was obtained by neutralization of $\mathrm{H}_{2} \mathrm{Ti}_{4} \mathrm{O}_{9}$ with $5 \mathrm{~N} n$-hexylamine. The amine-expanded compound was used for preparing an aluminium Keggin ion-pillared derivative by ion exchange with $\mathrm{Al}_{13}$ solution. In order to avoid competition of other cations for the ion-exchange sites of titanate, the $\mathrm{Al}_{13}$ Keggin ion solution was prepared by hydrolyzing the $\mathrm{AlCl}_{3}$ solution with $n$-hexylamine as base at $50^{\circ} \mathrm{C}$. The $\mathrm{pH}$ of the solution was kept at ca.4.2. The exchange temperature and solution concentration were normally $50^{\circ} \mathrm{C}$ and $0.3-0.6 N$ (in terms of $\mathrm{Al}$ ), respectively. The resultant compound was abbreviated as KPT. When layered titanate prepared by the hydrothermal method was used as starting material instead of $\mathrm{K}_{2} \mathrm{Ti}_{4} \mathrm{O}_{9}, n$-hexylammonium ion-expanded precursor was prepared by allowing the former to react with $1 \mathrm{~N}$ hexylammonium chloride solution directly.

The zirconium-pillared titanate was prepared by mixing powders of $n$-hexylammonium ionexpanded titanate with a $0.2 N \mathrm{ZrOCl}_{2}$ in $1 \mathrm{M}$ hexylammonium chloride solution $(\mathrm{pH} \sim 1)$ at $50^{\circ} \mathrm{C}$. The fresh solution of the latter was considered to contain mainly hydroxyzirconium tetramer cations.

The pillared products were washed thoroughly with deionized waster until the filtrate was free of $\mathrm{Cl}^{-}$ions.

\section{Characterization techniques}

XRD patterns were obtained on a Philips PW 1840 automated powder diffractometer, employing Ni-filtered $\mathrm{CuK} \alpha$ radiation. The diffuse reflectance UV-VIS spectra were recorded on a Hitachi Model U-3410 spectrometer. TGA and temperatureprogrammed desorption of ammonia were carried out on a Du Pont 951 TGA system. Surface area measurements were carried out volumetrically and surface area calculations were based on the BET theory. The $\mathrm{N}_{2}$ adsorption-desorption isotherms were obtained on a Cahn TG-121 system with a sensitivity on the order of $0.1 \mu \mathrm{g}$. The elemental analyses were carried out with a Jarrell-Ash Model ICAP 9000 ICP-AES system.

Catalytic experiments were carried out on a fixed-bed flow system at atmospheric pressure. The products were analyzed by gas chromatography. Samples of $1 \mathrm{wt} . \% \mathrm{Pt}$ supported on various pillared titanates were prepared by incipient wetness with $\mathrm{PtCl}_{6}^{2-}$ solutions. The $\mathrm{H}_{2}$ chemisorption isotherms were measured volumetrically at ambient temperatures in a Pyrex vacuum system with the vacuum pressure in the order of $1 \cdot 10^{-5}$ Torr. The $\mathrm{H}_{2}$ chemisorption capacity was determined by extrapolating the plateaus of the isotherms to the point of zero partial pressure.

\section{Results and discussion}

\section{Characterization of layered titanate}

The structure of titanate prepared by the hydrothermal method was compared with that of $\mathrm{K}_{2} \mathrm{Ti}_{4} \mathrm{O}_{9}$ prepared by the solid-state reaction. Fig. 1b shows that the former compound has several broad diffraction peaks; the one at the lowest angle corresponds to $d=10.7 \AA$. Because this distance was found to vary with different exchanged cations, it was considered to correspond to interlayer distance. On the other hand, the broadness of the peaks indicates that the compound has low crystallinity. Noteworthy, this interlayer distance is larger than the $8.7 \AA$ of $\mathrm{K}_{2} \mathrm{Ti}_{4} \mathrm{O}_{9}$ (Fig. la). Although various layered titanates have different interlayer spacings, those of the an-hydrated forms usually vary in the range $7.5-9.0 \AA$. The increment observed on the titanate prepared by the hydrothermal method is attributed to the accommodation of hydration water molecules in the interlayers. In order to identify the structure, this layered compound was calcined at higher temperatures. Fig. 1 shows that the compound becomes amorphous after calcination at $500^{\circ} \mathrm{C}$ and transforms to a single crystalline phase of $\mathrm{Na}_{2} \mathrm{Ti}_{6} \mathrm{O}_{13}$ after calcination at $800^{\circ} \mathrm{C}$.

The TGA curve of the layer compound shows that a two-step weight loss occurred mainly below $300^{\circ} \mathrm{C}$ (Fig. 2A). The first step, which occurred below $128^{\circ} \mathrm{C}$, was due to the evolution of water of hydration. The second weight loss, which actually overlaps with the first step and extends to ca. $500^{\circ} \mathrm{C}$, is ascribed to the dehydroxylation of the $\mathrm{Ti}-\mathrm{OH}$ groups of titanate. In order to get a better 


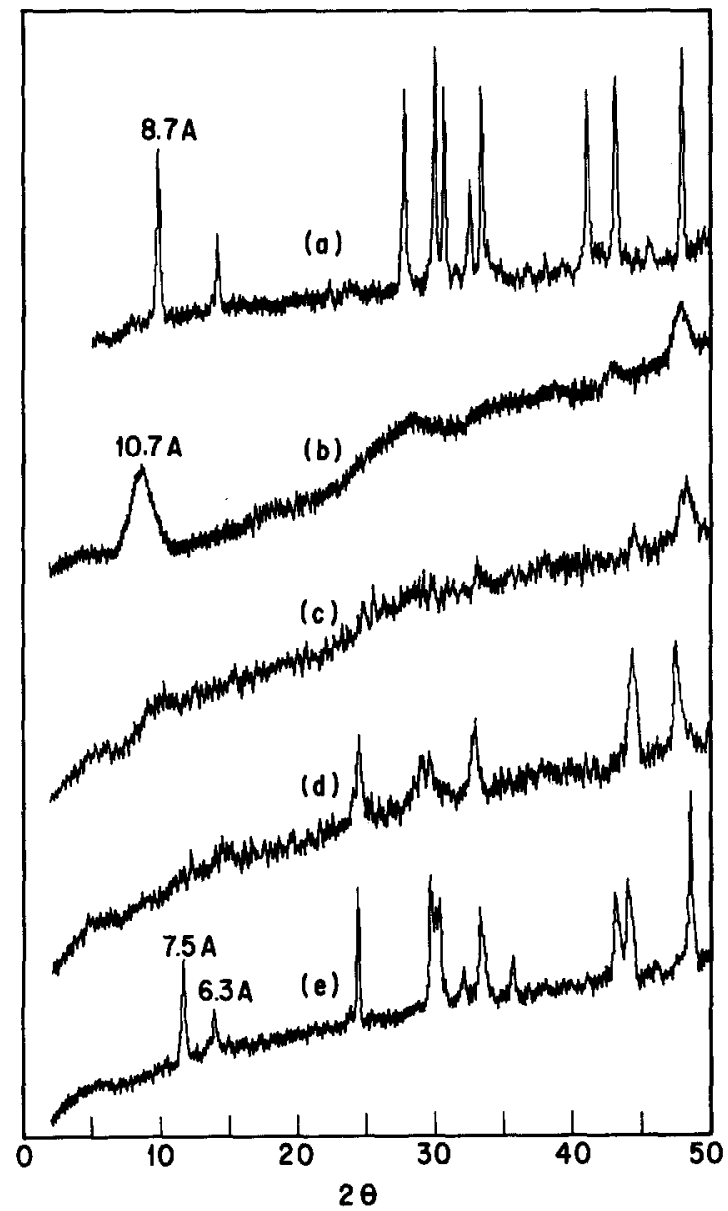

Fig. 1. XRD patterns of (a) $\mathrm{K}_{2} \mathrm{Ti}_{4} \mathrm{O}_{9}$, (b) as-synthesized LTO, and LTO calcined at (c) $500^{\circ} \mathrm{C}$, (d) $600^{\circ} \mathrm{C}$ and (e) $800^{\circ} \mathrm{C}$.

resolution of these two weight losses, the TGA of the same sample was run in a dynamic way, where the heating rate was set at $10^{\circ} \mathrm{C} / \mathrm{min}$ from room temperature to $100^{\circ} \mathrm{C}$, isothermal for $1 \mathrm{~h}$, then $5^{\circ} \mathrm{C} / \mathrm{min}$ to $600^{\circ} \mathrm{C}$. Fig. 2 shows that a $12.4 \%$ weight loss occurred below $100^{\circ} \mathrm{C}$ and a $3.0 \%$ loss from 100 to $530^{\circ} \mathrm{C}$. The broad shape of the latter weight loss is attributed to dehydroxylation of the structures of low crystallinity. The elemental analysis data, shown in Table 1 , indicate that the $\mathrm{Na} / \mathrm{Ti}$ molar ratio of the titanate prepared by the hydrothermal method has a value of 0.392 . Based on these results, we concluded that layered titanate has a composition close to the formula $\mathrm{Na}_{1,17} \mathrm{H}_{0.83} \mathrm{Ti}_{3} \mathrm{O}_{7} \cdot 2 \mathrm{H}_{2} \mathrm{O}$, which is a hydrated
TABLE 1

ICP-AES elemental analysis data of titanates

\begin{tabular}{lll}
\hline $\begin{array}{l}\text { Compound/ } \\
\text { element }\end{array}$ & $\begin{array}{l}\text { Concentration } \\
(\mathrm{ppm})\end{array}$ & $\begin{array}{l}\text { Relative } \\
\text { molar ratio }\end{array}$ \\
\hline $\begin{array}{l}\text { Layered } \\
\mathrm{Na}\end{array}$ & $\begin{array}{l}\text { oxide }(\text { LTO }) \\
\mathrm{Ti}\end{array}$ & 0.065 \\
$\mathrm{Al}$ & -346 & 0.392 \\
$\mathrm{Zr}$ & - & - \\
$A l_{13}-L T O, 500^{\circ} \mathrm{C}$ & & - \\
$\mathrm{Na}$ & - & \\
$\mathrm{Ti}$ & 0.113 & - \\
$\mathrm{Al}$ & 0.065 & 1.000 \\
$\mathrm{Zr}$ & - & 1.018 \\
$\mathrm{Zr},-L T O, 500^{\circ} \mathrm{C}$ & & - \\
$\mathrm{Na}$ & - & \\
$\mathrm{Ti}$ & 0.147 & - \\
$\mathrm{Al}$ & - & 1.000 \\
$\mathrm{Zr}$ & 0.098 & - \\
\hline
\end{tabular}

sodium hydrogentrititanate. This compound will be abbreviated as LTO (layered titanium oxide) hereafter. A similar compound was reported by Izawa et al. [22] by partial ion exchange of the $\mathrm{Na}^{+}$ions of $\mathrm{Na}_{2} \mathrm{Ti}_{3} \mathrm{O}_{7}$ with acid. The formation of an $\mathrm{Na}_{2} \mathrm{Ti}_{6} \mathrm{O}_{13}$ phase after dehydroxylation of LTO at high temperatures also confirmed its composition.

\section{Synthesis of amine-intercalated precursors}

The $n$-hexylammonium-intercalated complexes were prepared by interaction of amine with layered titanates in either partially or completely $\mathrm{H}^{+}$. exchanged form. The mechanism was proposed by Izawa et al. [23] who stated that a combination of intercalation and ion-exchange processes was responsible for the formation of the amineintercalated complexes. Fig. $3 a$ and $c$ show the XRD patterns of tetratitanate $\left(\mathrm{K}_{2} \mathrm{Ti}_{4} \mathrm{O}_{9}\right)$ and LTO, respectively, after hexylamine intercalation. For tetratitanate, the amine expands the interlayer distance from 8.7 to $21.6 \AA$. In the case of LTO, the change is from 10.7 to $22.7 \AA$. The similarity in interlayer distances of these two amine-expanded samples implies that they probably have similar zigzag layered structures. Since alkyl chains grow by $1.27 \AA$ per added carbon, the expanded dis- 

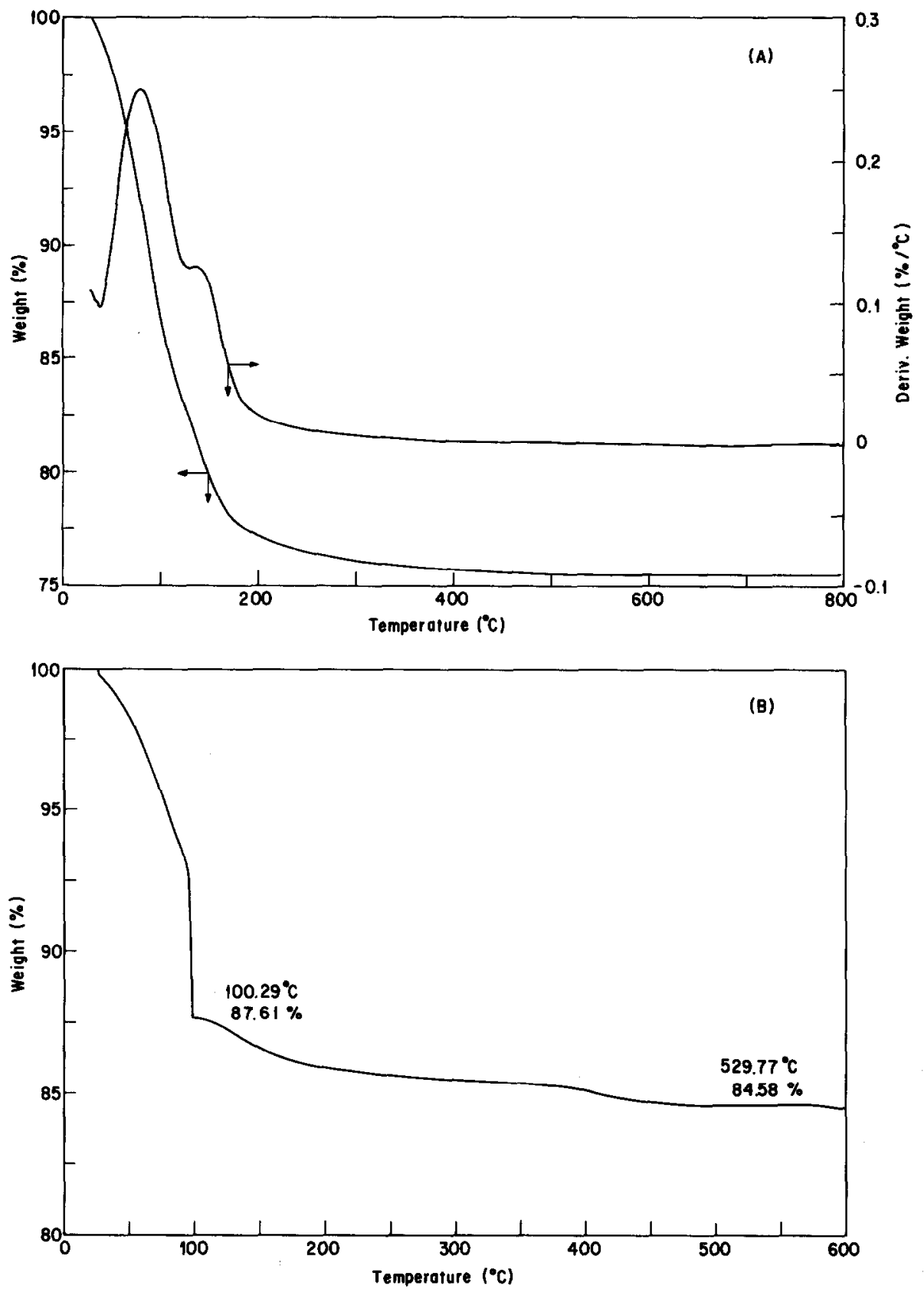

Fig. 2. TGA (A) and DTG (B) profiles of the as-synthesized LTO.

tances $(>12 \AA)$ suggest that the hexylammonium ions form double layers with the $-\mathrm{NH}_{3}^{+}$groups pointing toward the basal titanate layers.

The interlayer hexylammonium ions were found to be replaceable with $\mathrm{Na}^{+}$ions and the interlayer distance of $10.4 \AA$ was regained when the amineintercalated complex was stirred with $1 N \mathrm{NaCl}$ solution at ambient temperature for one day. 


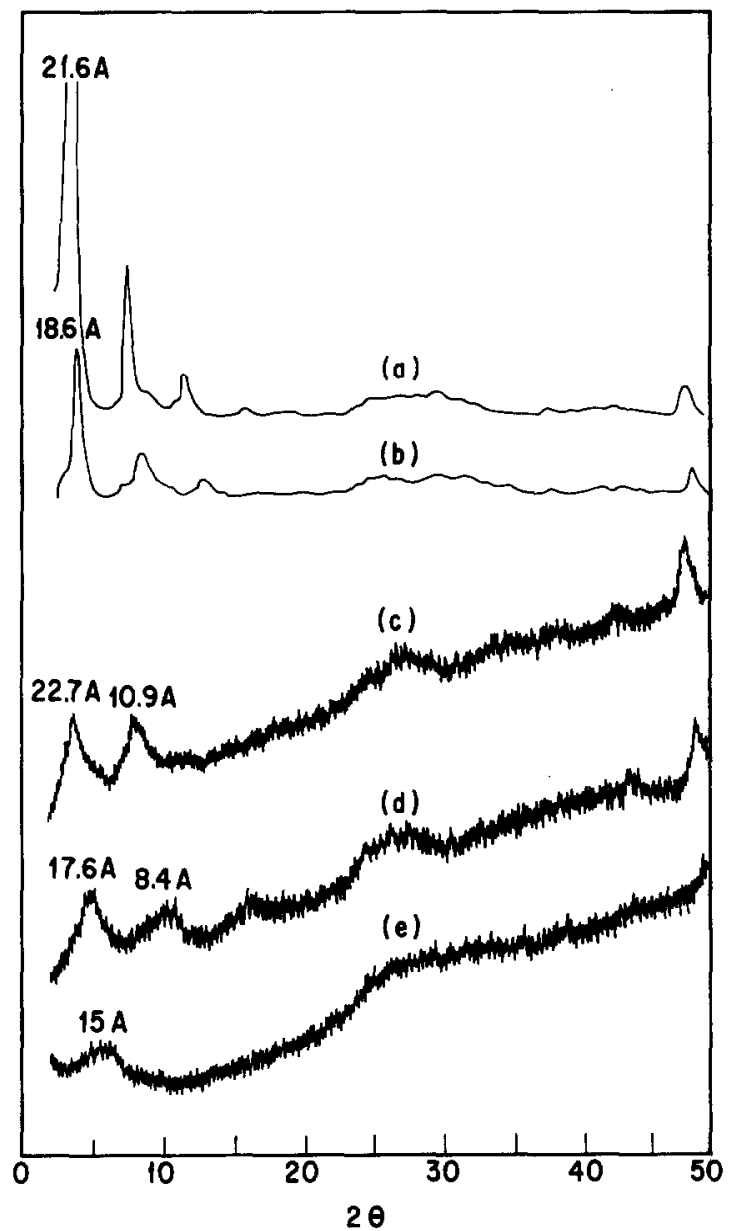

Fig. 3. XRD patterns of (a) hexylamine- $\mathrm{Ti}_{4} \mathrm{O}_{9}$, (b) $\mathrm{Al}_{13}-\mathrm{Ti}_{4} \mathrm{O}_{9}$, (c) hexylamine-LTO, (d) $\mathrm{Al}_{13}-\mathrm{LTO}$, and (e) $\mathrm{Zr}_{4}-$ LTO.

\section{Preparation of polyoxo metal ion-pillared titanates}

The hexylamine-intercalated complexes were used as precursors for the pillaring of titanates with polyoxo cations of aluminium and zirconium. The expanded interlayer spacings facilitated the migration of bulky inorganic ions towards the interlayer ion-exchange sites. Fig. $3 b$ and d correspond to the XRD patterns of $\mathrm{Al}_{13}$ ion-exchange titanates prepared by the solid-state reaction (KPT) and the hydrothermal method (termed $\mathrm{Al}_{13}-\mathrm{LTO}$ ), respectively. A shift of the first peaks to lower $d$ spacings was found, i.e., 21.6 to $18.6 \AA$ for $\mathrm{KPT}$ and 22.7 to $c a$. $17.6 \AA$ for $-\mathrm{Al}_{13}-$ LTO. When the amine-expanded titanates were exchanged with $\mathbf{Z r}_{\mathbf{4}}$ cations, the tetratitanate sample gave an XRD pattern very similar to that of $\mathrm{H}_{2} \mathrm{Ti}_{4} \mathrm{O}_{9} \cdot \mathrm{H}_{2} \mathrm{O}$ with an interlayer distance of ca. $9.1 \AA$ (not shown in the figure), while the LTO sample had a fused diffraction peak at ca. $15 \AA$ (Fig. 3e). The thickness of the layered titanates, e.g. $\mathrm{Ti}_{4} \mathrm{O}_{9}^{2-}$ and $\mathrm{Ti}_{3} \mathrm{O}_{7}^{2-}$ layers, estimated by subtracting the diameter of $\mathrm{K}^{+}$ions $(3.0 \AA)$ from the interlayer distance of $\mathrm{K}_{2} \mathrm{Ti}_{4} \mathrm{O}_{9}(8.7 \AA)$ and that of $\mathrm{Na}^{+}$ions $(2.5 \AA)$ from $\mathrm{Na}_{2} \mathrm{Ti}_{3} \mathrm{O}_{7}(8.6 \AA)$ is ca. 5.7-6.1 $\AA$. If the LTO has its basal layers in similar zigzag arrangement of $\mathrm{TiO}_{6}$ octahedra as in $\mathrm{K}_{2} \mathrm{Ti}_{4} \mathrm{O}_{9}$ and $\mathrm{Na}_{2} \mathrm{Ti}_{3} \mathrm{O}_{7}$, it shall have a layer thickness close to $6 \AA$. Since $\mathrm{Zr}_{4}$ cations have a diameter of ca. $9 \AA$, the $15-\AA$ interlayer distance observed on $\mathbf{Z r}_{4}$-exchanged titanate fits well with the expected value. This $\mathbf{Z r}_{4}$ exchanged LTO is abbreviated as $\mathbf{Z r}_{4}-$ LTO. The above results also demonstrate that $\mathrm{H}^{+}$ions present in the $\mathrm{ZrOCl}_{2}$ solution are strong competitors for ion-exchange sites and that the exchange of interlayer hexylammonium ions with $\mathrm{Zr}_{4}$ cations is seriously affected by the crystallinity of the layered titanates. In other words, because protons diffused much faster than the bulky $\mathrm{Zr}_{4}$ cations, the high crystallinity of the material restrained the $\mathrm{Zr}_{4}$ cations from easily diffusing into the interlayer space. As a result, $\mathrm{H}^{+}$-exchanged tetratitanate was obtained instead. A similar crystallinity effect was not observed on the $\mathrm{Al}_{13}$-exchange process, probably because the proton concentration in the hydrolyzed $\mathrm{AlCl}_{3}$ solution was much lower than that in a $\mathrm{ZrOCl}_{2}$ solution.

The chemical analysis results shown in Table 1 show that most of the $\mathrm{Na}^{+}$ions in the interlayers have been replaced after the pillaring reaction. $\mathrm{Al} / \mathrm{Ti}$ and $\mathrm{Zr} / \mathrm{Ti}$ molar ratios of 1.02 and 0.349 , respectively, imply that ca. 82.2 and $105 \%$ of the ion-exchange sites of $\mathrm{Na}_{1.17} \mathrm{H}_{0.83} \mathrm{Ti}_{3} \mathrm{O}_{7}$ were occupied by $\mathrm{Al}_{13}$ and $\mathrm{Zr}_{4}$ ions if they have charges of +7 and +8 , respectively. The excess of $100 \%$ exchange for $\mathrm{Zr}_{4}-$ LTO indicates that a portion of the $\mathrm{Zr}_{4}$ ions probably has been further hydrolyzed and carries a charge of +2 instead of +8 [24].

\section{Thermal stability of pillared titanates}

Fig. 4 shows the $\mathrm{XRD}$ patterns of the $\mathrm{Al}_{13^{-}}$ pillared LTO after calcination at various temper- 


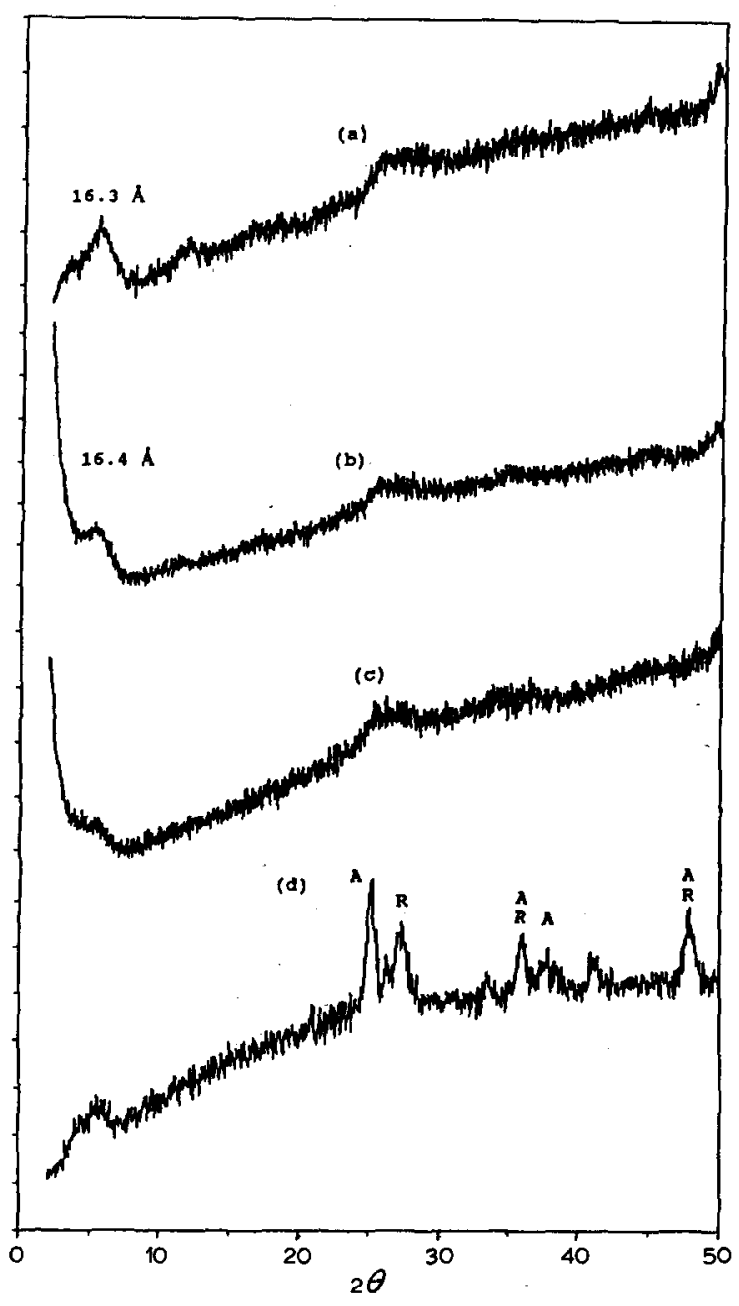

Fig. 4. $\mathrm{XRD}$ patterns of $\mathrm{Al}_{13}-\mathrm{LTO}$ after calcination at (a) $500^{\circ} \mathrm{C}$, (b) $600^{\circ} \mathrm{C}$, (c) $700^{\circ} \mathrm{C}$ and (d) $800^{\circ} \mathrm{C}$. $\mathrm{A}=$ Analase; $\mathrm{R}=$ rutile.

atures. The first diffraction peak was found to shift towards lower $d$ spacing, from 17.6 to $16.3 \AA$, after the compound was calcined at $500^{\circ} \mathrm{C}$. That interlayer distance was retained up to $600^{\circ} \mathrm{C}$ calcination. When the sample was calcined at $700^{\circ} \mathrm{C}$, some new peaks developed, which grew to sharp peaks corresponding to anatase and rutile $\mathrm{TiO}_{2}$ phases after $800^{\circ} \mathrm{C}$ calcination. Accordingly, the structure of $\mathrm{Al}_{13}-\mathrm{LTO}$ was thermally stable to $c a$. $600^{\circ} \mathrm{C}$. The large $d$ spacings observed on samples before calcination are attributed to the observation that some hexylammonium ions were still present in the interlayers. The organic species were then burned off during calcination and only the inorganic Keggin ions were left as pillars. The diameter of aluminium Keggin ions has been determined, both theoretically [25] and by small angle scattering [26], to be $c a .8 .6 \AA$. Using the estimated thickness of titanate layers of ca. $6 \AA$, the interlayer distance of $16.3 \AA$ implies that each Keggin ion with a spherical shape spans more than a unit cell in the $b$ direction.

The $\mathrm{Zr}_{4}$-pillared LTO was not as thermally stable as $\mathrm{Al}_{13}$-pillared LTO. Fig. 5 shows that the compound becomes amorphous after calcination

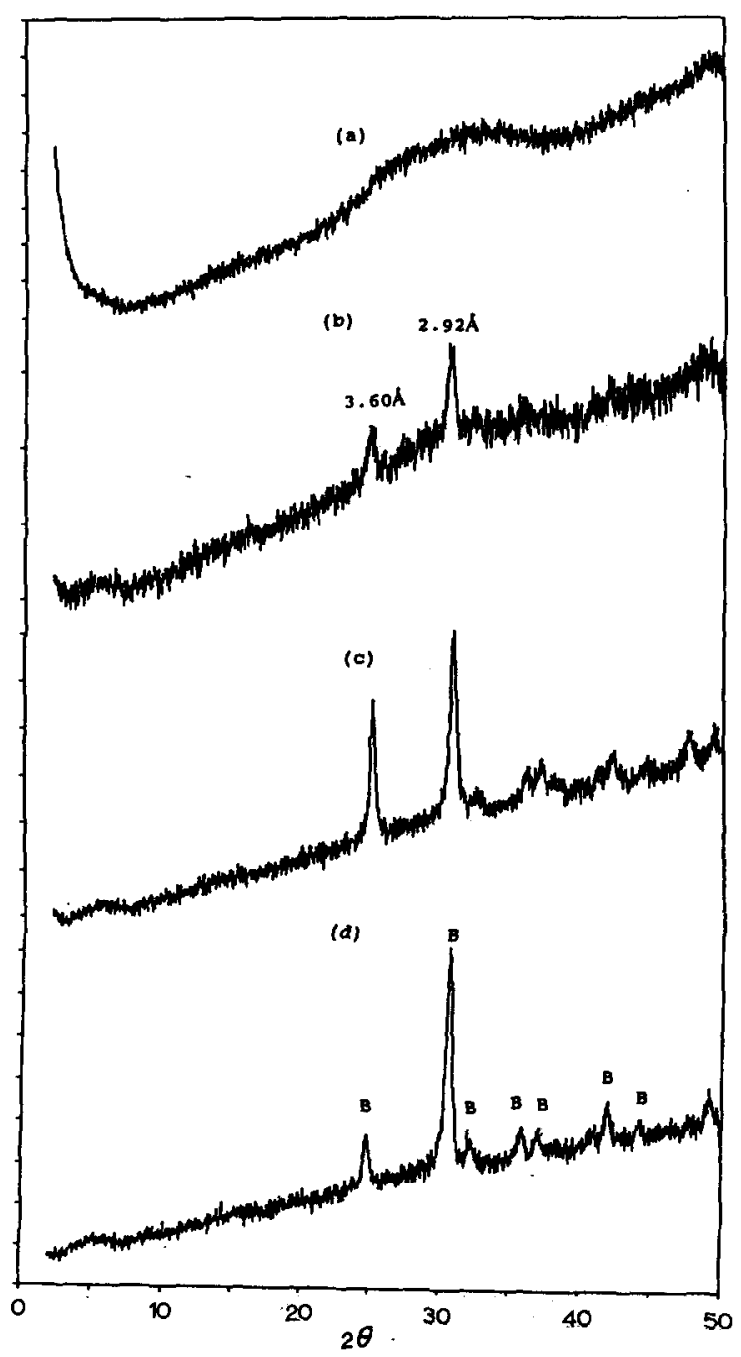

Fig. 5. XRD patterns of $\mathrm{Zr}_{4}$-LTO after calcination at (a) $100-500^{\circ} \mathrm{C}$, (b) $600^{\circ} \mathrm{C}$, (c) $700^{\circ} \mathrm{C}$ and (d) $800^{\circ} \mathrm{C}$. $\mathrm{B}=$ brookite. 
in the temperature range $100-500^{\circ} \mathrm{C}$ and transforms to brookite phase after calcination at temperatures higher than $600^{\circ} \mathrm{C}$.

\section{BET surface area and porosity}

The surface areas of titanates before and after the pillaring reaction are shown in Table 2. Before the measurement, all compounds (except those specified) were evacuated at ca. $200^{\circ} \mathrm{C}$ for $2 \mathrm{~h}$. The starting material, $\mathrm{K}_{2} \mathrm{Ti}_{4} \mathrm{O}_{9}$, which was prepared by the solid-state method, has a relatively low surface area $\left(13 \mathrm{~m}^{2} / \mathrm{g}\right)$, while that prepared by the hydrothermal method, LTO (evacuated at $120^{\circ} \mathrm{C}$ ), has a larger surface area of ca. $97 \mathrm{~m}^{2} / \mathrm{g}$. The latter was not thermally stable, however, and its surface area shrank to $3 \mathrm{~m}^{2} / \mathrm{g}$ after calcination at $500^{\circ} \mathrm{C}$, accompanied by a structural transformation described in the previous section. The surface areas of $\mathrm{Al}_{13}$-pillared derivatives after calcination at $500^{\circ} \mathrm{C}$ increased by about five times and more than fifty times over that of $\mathrm{K}_{2} \mathrm{Ti}_{4} \mathrm{O}_{9}$ and calcined LTO, respectively. The LTO of low crystallinity and higher surface area is apparently more favorable as starting material in preparing pillared titanate of high surface area. This is attributed to the observation that a higher surface area facilitates

TABLE 2

BET surface areas of titanates

\begin{tabular}{lc}
\hline Compound & $\begin{array}{c}\text { Surface area } \\
\left(\mathrm{m}^{2} / \mathrm{g}\right)\end{array}$ \\
\hline $\mathrm{K}_{2} \mathrm{Ti}_{4} \mathrm{O}_{9}{ }^{\mathrm{a}}$ & 13 \\
$\mathrm{Al}_{13}-\mathrm{Ti}_{4} \mathrm{O}_{9}(\mathrm{KPT})$ & 62 \\
$\mathrm{LTO}, \mathrm{Na}_{1.17} \mathrm{H}_{0.83} \mathrm{Ti}_{3} \mathrm{O}_{7}{ }^{\mathrm{b}}$ & 97 \\
$\mathrm{LTO}, 500^{\circ} \mathrm{C}$ & 3 \\
$\mathrm{Al}_{13}-\mathrm{LTO}, 500^{\circ} \mathrm{C}$ & 170 \\
$\mathrm{Al}_{13}-\mathrm{LTO}, 600^{\circ} \mathrm{C}$ & 125 \\
$\mathrm{Al}_{13}-\mathrm{LTO}, 700^{\circ} \mathrm{C}$ & 121 \\
$\mathrm{Al}_{13}$-LTO, $800^{\circ} \mathrm{C}$ & 61 \\
$\mathrm{Na}^{+}$-exchanged $\mathrm{Al}_{13}$-LTO & 322 \\
$\mathrm{Na}^{+}$-exchanged $\mathrm{Al}_{13}-\mathrm{LTO}, 500^{\circ} \mathrm{C}$ & 237 \\
$\mathrm{Zr}_{4}-\mathrm{LTO}, 500^{\circ} \mathrm{C}$ & 162 \\
$\mathrm{Zr}_{4}-\mathrm{LTO}, 700^{\circ} \mathrm{C}$ & 34 \\
$\mathrm{Na}^{+}$-exchanged $\mathrm{Zr}_{4}-\mathrm{LTO}$ & 264 \\
$\mathrm{Na}^{+}$-exchanged $\mathrm{Zr}_{4}$-LTO, $500^{\circ} \mathrm{C}$ & 128 \\
$\mathrm{Na}^{+}$-exchanged amine-LTO, $500^{\circ} \mathrm{C}$ & 4 \\
\hline
\end{tabular}

asolid state method.

bHydrothermal method. the access of pillar cations to the interlayer space. Nevertheless, the surface area of the pillared products decreased gradually as the calcination temperature was raised. On the other hand, the $500^{\circ} \mathrm{C}$ calcined $\mathrm{Zr}_{4}$-LTO also has a surface area of $c a$. $162 \mathrm{~m}^{2} / \mathrm{g}$, even though it is amorphous.

The pillaring reaction was found to be basically irreversible. When the uncalcined $\mathrm{Al}_{13}-$ and $\mathrm{Zr}_{4}$-LTO complexes were stirred with $1 N \mathrm{NaCl}$ solution for one day, the XRD patterns showed that the interlayer distances of the resulting compounds were unchanged. Nevertheless, the surface areas were increased from 170 to $322 \mathrm{~m}^{2} / \mathrm{g}$ and 162 to $264 \mathrm{~m}^{2} / \mathrm{g}$, respectively, after the $\mathrm{Al}_{13}$ - and $\mathrm{Zr}_{4}-\mathrm{LTO}$ complexes were evacuated at $120^{\circ} \mathrm{C}$. This is attributed to the fact that through the $\mathrm{Na}^{+}$ ion-exchange process, the remaining hexylammonia ions and surface polyoxo cations, which may block the entrance of the pores, are removed. However, the surface areas shrank after these compounds were calcined at $500^{\circ} \mathrm{C}$ to 237 and $128 \mathrm{~m}^{2} / \mathrm{g}$, respectively. The latter is less than that of the original $\mathrm{Zr}_{4}$-LTO complexes. In other words, $\mathrm{Na}^{+}$exchange has made the $\mathrm{Zr}_{4}$-pillared structure less thermally stable. This is probably due to the fact that some of the interlayer $\mathrm{Zr}_{4}$ pillars are also removed during the $\mathrm{Na}^{+}$exchange process. Furthermore, these $\mathbf{Z r}_{\mathbf{4}}$ pillars must have $a+2$ instead of +8 charge to be exchangeable by $\mathrm{Na}^{+}$ions. On the contrary, the exchange of interlayer $\mathrm{Al}_{13}$ pillars in $\mathrm{Al}_{13}-\mathrm{LTO}$ by $\mathrm{Na}^{+}$ions is considered to be neglegible, due to its +7 charge. For comparison, an amine-intercalated precursor was found to be reversibly exchanged with $\mathrm{NaCl}$. After calcination at $500^{\circ} \mathrm{C}$, it had a surface area of $4 \mathrm{~m}^{2} / \mathrm{g}$. These results strongly support the idea that the increase in surface areas of the pillared compounds is due to the interlayer spaces being propped open by the polyoxo cation pillars.

The $\mathrm{N}_{2}$ adsorption-desorption isotherms of the pillared samples calcined at $500^{\circ} \mathrm{C}$ are shown in Fig. 6. The steep increase in adsorption at low partial pressure is due to the condensation of $\mathrm{N}_{2}$ in the microporous structures, and the amount of $\mathrm{N}_{2}$ adsorbed in this region is determined by the volume of micropores in the solid. Accordingly, both $\mathrm{Al}_{13^{-}}$and $\mathrm{Zr}_{4}$-pillared LTOs have a larger micropore volume, while pillared tetratitanate, 

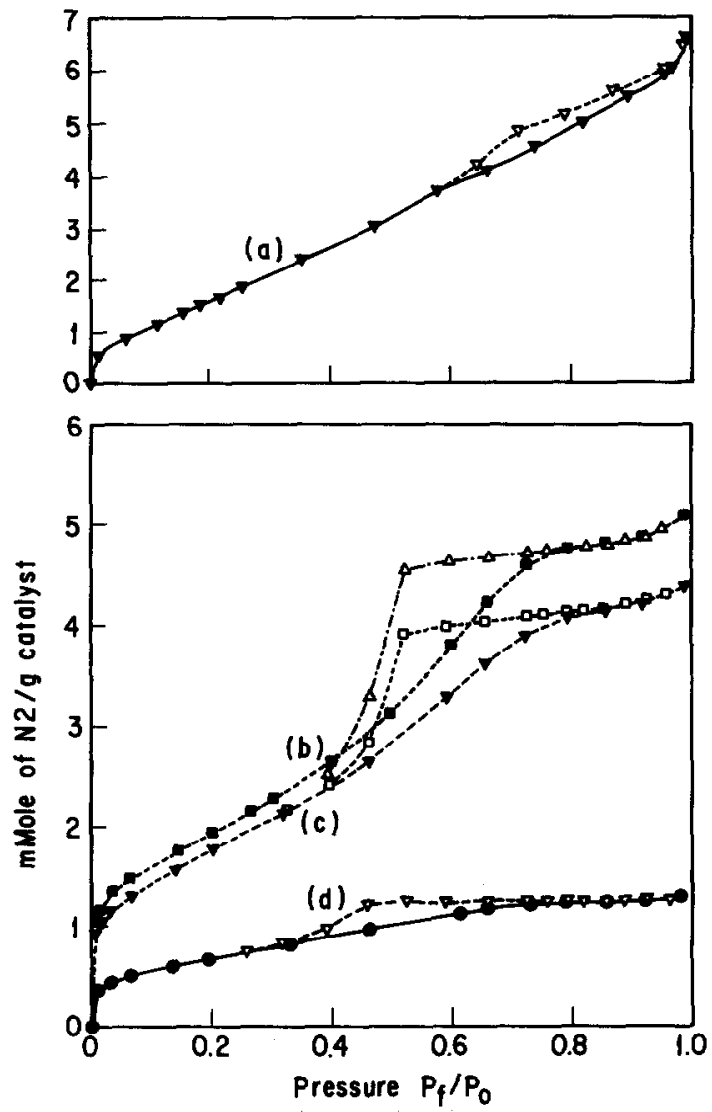

Fig. 6. $\mathrm{N}_{2}$ adsorption-desorption isotherms of pillared titanates: (a) KPT; (b) $\mathrm{Al}_{13}-\mathrm{LTO}$; (c) $\mathrm{Zr}_{4}-\mathrm{LTO}$ after $500^{\circ} \mathrm{C}$ calcination; (d) LTO evacuated at $120^{\circ} \mathrm{C}$.

KPT, has a lower micropores volume. Since the microporous structures result from the interlayer void propped open by the pillar species, this implies that the polyoxo pillars are more homogeneously distributed in the interlayers of the LTO samples than in tetratitanate. The presence of a large amount of micropores in the $\mathrm{Zr}_{4}$-LTO sample (after calcination at $500^{\circ} \mathrm{C}$ ) was a strong indication that the pillared layer structures were retained although the basal layers were not aligned as in the $\mathrm{Al}_{13}$-pillared sample, so that it seemed to be amorphous on the X-ray diffractogram. The discrepancy in crystallinity and thermal stability between $\mathrm{Al}_{13}$ - and $\mathrm{Zr}_{4}$-pillared LTOs can be elucidated by the shapes of the pillars. Different from the $\mathrm{Al}_{13}$ cation, which has a spherical shape, the $\mathrm{Zr}_{4}$ cation has the shape of a platelet. The latter is more easy to tilt in between the interlayers and results in a less ordered pillared product. On the other hand, the hysteresis, which corresponded to mesoporous structures, was observed in the isotherms of all the pillared samples. These mesopores probably originated from portions of the particles with pillars not homogeneously distributed in between the layers as well as defects from delamination.

Since both $\mathrm{Al}_{13^{-}}$and $\mathrm{Zr}_{4}$-pillared LTOs after calcination at $500^{\circ} \mathrm{C}$ exhibited high surface areas and porous structures, they were subject to further characterization.

\section{Characteristic properties of pillared titanates}

\section{Absorption spectra}

Fig. 7 shows the absorption spectra of $\mathrm{Al}_{13}$ - and $\mathrm{Zr}_{4}$-pillared LTOs in the UV-VIS region, compared to that of bulk $\mathrm{TiO}_{2}$ (anatase form) and the non-pillared LTO. These compounds all have two overlapped absorption bands in the range 200-400 nm; there are some differences in the band width and band shape however. The absorption threshold is estimated from the extrapolation of the rising portion of the spectrum to the abscissa, as shown in Fig. 7. The bulk $\mathrm{TiO}_{2}$ has a threshold at ca. $397 \mathrm{~nm}$, which is in good agreement with that observed on $\mathrm{TiO}_{2}$ dispersed in water [27]. The non-pillared LTO has a narrower band width than bulk $\mathrm{TiO}_{2}$, and shows a blue shift of the threshold to $c a .380 \mathrm{~nm}$. On the other hand, the incorporation of different pillaring species changes the threshold to different extents: the $\mathrm{Al}_{13}$-pillared LTO has the threshold kept around $380 \mathrm{~nm}$, while the $\mathrm{Zr}_{4}$-pillared LTO shows a red shift back to $c a$. $401 \mathrm{~nm}$. The blue shift of the absorption threshold suggests that the non-pillared and $\mathrm{Al}_{13}$-pillared LTOs have greater bandgaps than that of bulk $\mathrm{TiO}_{2}$ and $\mathrm{Zr}_{4}$-pillared LTO, but the increment is only $c a .0 .18 \mathrm{eV}$. Therefore, it may be concluded that the electron energy levels of the pillared LTOs are all in a range close to that of the bulk $\mathrm{TiO}_{2}$.

\section{Acidity of pillared titanate}

The acidity of pillared titanates was examined by carrying out temperature-programmed desorption of $\mathrm{NH}_{3}$ over the samples calcined at $500^{\circ} \mathrm{C}$. 


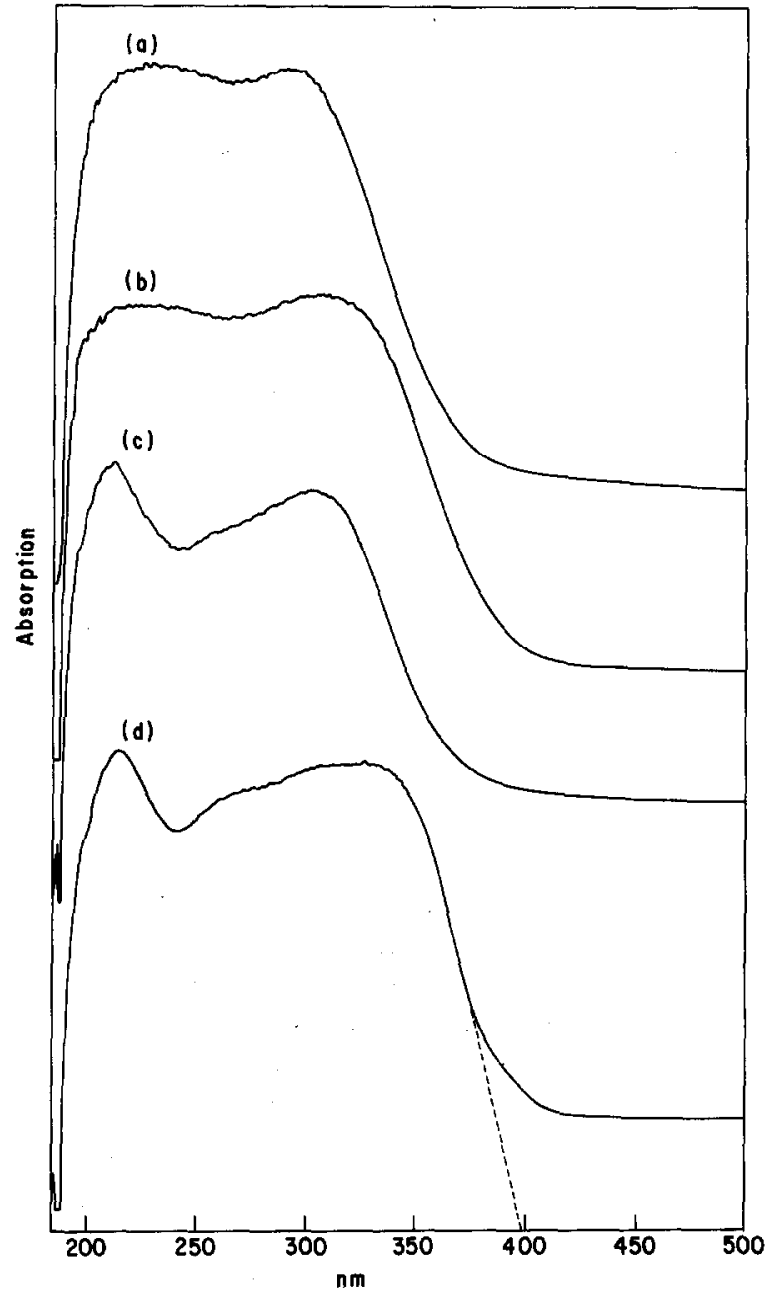

Fig. 7. Absorption spectra of (a) $\mathrm{Al}_{13}-\mathrm{LTO}$, (b) $\mathrm{Zr}_{4}-\mathrm{LTO}$, (c) LTO and (d) $\mathrm{TiO}_{2}$ (anatase).

Fig. 8 compares the temperature-programmed desorption profiles of the pillared samples with those of non-pillared LTO. The latter has almost no acidic sites. In contrast, the $\mathrm{Al}_{13}$-pillared LTO has the highest acid strength and contains the largest proportion of acidic sites among these three samples. The maximum of its temperatureprogrammed desorption profile appeared at $c a$. $260^{\circ} \mathrm{C}$ and was about $10^{\circ} \mathrm{C}$ higher than that of $\mathrm{Zr}_{4}$-pillared sample.

When the $500^{\circ} \mathrm{C}$-calcined $\mathrm{Al}_{13}$-pillared titanate was used as a catalyst for 2-propanol decomposition in the temperature range $190-300^{\circ} \mathrm{C}$, propyl- ene was obtained through the dehydration reaction, and no acetone from dehydrogenation was observed. These results imply that $\mathrm{Al}_{13}$-pillared titanate is an acid catalyst. However, in the methanol conversion reaction carried out at one atmospheric pressure and $350-400^{\circ} \mathrm{C}$, dimethyl ether was the major product, while minor amounts of $\mathrm{C}_{1}-\mathrm{C}_{4}$ hydrocarbons were also obtained. These catalytic behaviors are consistent with the acidity measurement result that $\mathrm{Al}_{13}$ ion-pillared titanate has a weak acidity.

\section{Strong metal-support interaction of Pt on pillared titanates}

The SMSI phenomenon was examined by comparing the hydrogen chemisorption capacity of $\mathrm{Pt}$ (1 wt.\%) supported on pillared titanates after it was reduced at 200 and $500^{\circ} \mathrm{C}$ (designated as LTR and HTR, respectively), as well as through the HTR-HTO-LTR cycle. HTO is the abbreviation of high-temperature oxidation, i.e., oxidation at $500^{\circ} \mathrm{C}$. Table 3 shows the results of $\mathrm{H}_{2}$ chemisorption data over Pt supported on pillared titanates, KPT, $\mathrm{Al}_{13}-$ LTO and $\mathrm{Zr}_{4}$-LTO. Because the pillared LTO samples have much higher surface areas than pillared tetratitanate, Pt metal is better dispersed on the former supports and a higher value

TABLE 3

$\mathrm{H}_{2}$ chemisorption on $\mathrm{Pt}$ supported on Keggin ion-pillared titanate

\begin{tabular}{llll}
\hline Support & $\begin{array}{l}\text { Reduction } \\
\text { temperature }\left({ }^{\circ} \mathrm{C}\right)\end{array}$ & $\begin{array}{l}\text { H/Pt } \\
\text { ratio }\end{array}$ & $\begin{array}{l}\text { BET surface } \\
\text { area }\left(\mathrm{m}^{2} / \mathrm{g}\right)\end{array}$ \\
\hline KPT (A) & 200 & 0.32 & 62 \\
& 500 & 0.16 & 74 \\
& HTR-HTO-LTR & 0.29 & 69 \\
KPT (B) & 200 & 0.43 & 33 \\
& 500 & 0.13 & 37 \\
& HTR-HTO-LTR & 0.42 & 34 \\
Al $_{13}$ LTO (A) & 200 & 0.78 & 179 \\
& 500 & 0.17 & 180 \\
& HTR-HTO-LTR & 0.22 & 181 \\
$\mathrm{Al}_{13}$ LTO (B) & 200 & 0.69 & 164 \\
& 500 & 0 & 167 \\
& HTR-HTO-LTR & 0.27 & 168 \\
$\mathrm{Zr}_{4}$-LTO & 200 & 0.51 & 159 \\
& 500 & 0 & 151 \\
& HTR-HTO-LTR & 0.28 & 154 \\
\hline
\end{tabular}

'Samples A and B are from different batches. 


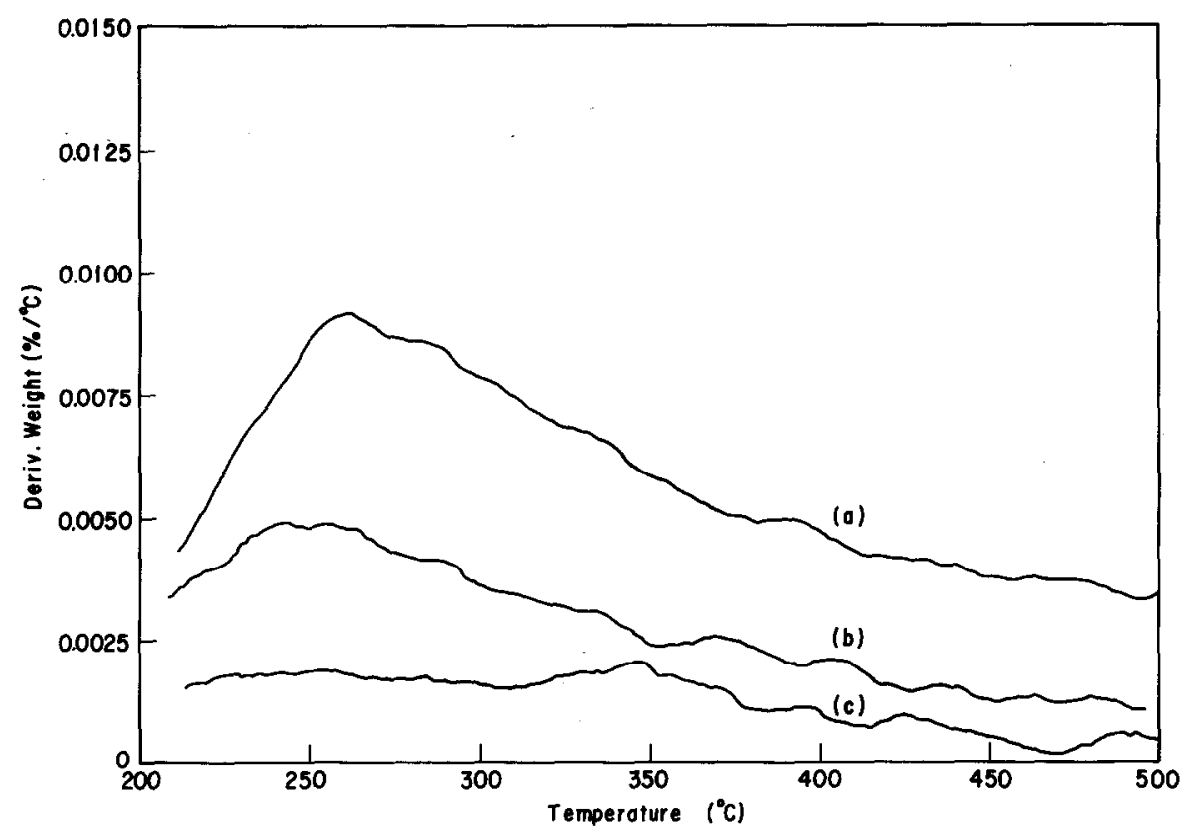

Fig. 8. Temperature-programmed desorption profiles of $\mathrm{NH}_{3}$ over (a) $\mathrm{Al}_{13}-\mathrm{LTO}$, (b) $\mathrm{Zr}_{4}-\mathrm{LTO}$ and (c) LTO after $500^{\circ} \mathrm{C}$ calcination.

of $\mathrm{H} / \mathrm{Pt}$ has been obtained. Nevertheless, for all these samples, the chemisorption capacity was apparently suppressed after HTR and recovered through the HTR-HTO-LTR cycle. However, the extent of recovery varied with the layered materials. Among them, that of the KPT series was found to be completely recovered, while those of $\mathrm{Al}_{13}$ - and $\mathrm{Zr}_{4}$-LTOs were only partially recovered. However, the transmission electron microscopic pictures taken over the reduced samples showed no obvious sintering of $\mathrm{Pt}$ particles. Neither did the X-ray diffractograms detect crystalline $P t$ particles. These results imply that the pillared titanates are likely to retain the characteristic properties of $\mathrm{TiO}_{2}$ as a support. To date, reasons for the different recovery on the pillared titanates in $\mathrm{H}_{2}$ chemisorption through the HTR-HTO-LTR cycle are not known. Further investigation is continuing in our laboratory.

\section{Conclusions}

A pillaring reaction was applicd successfully to layered titanate of low crystallinity with polyoxo cations of aluminium and zirconium, and titanium oxide-based compounds with high surface areas and porosity were obtained. The physiochemical properties of the pillared compounds were modified by varying the pillar species. The electronic energy levels of both $\mathrm{Al}_{13}-$ and $\mathrm{Zr}_{4}$-pillared titanates are close to that of bulk $\mathrm{TiO}_{2}$. The $\mathrm{Al}_{13}$-pillared titanate has a bandgap ca. $0.18 \mathrm{eV}$ greater than $\mathrm{Zr}_{4}$ pillared titanate, and the latter has a value almost the same as that of bulk $\mathrm{TiO}_{2}$. Acidic sites were built on pillared titanates with either $\mathrm{Al}_{13}$ or $\mathrm{Zr}_{4}$ polycations as pillars, while the former gave higher acidity. The SMSI phenomenum was observed on Pt supported on these pillared titanates.

\section{Acknowledgement}

Financial support from the National Science Council of the Republic of China is gratefully acknowledged.

\section{References}

1 I. Izumi, W.W. Dunn, K.O. Wilboun, F.F. Fan and A.J. Bard, J. Phys. Chem., 84 (1980) 3207. 
2 S. Tauster, S.C. Fung and R.L. Garten, J. Am. Chem. Soc., 100 (1978) 170.

3 S. Matsuda, M. Takeuchi, T. Hishinuma, F. Nakajima, T. Narita, Y. Watanabe and M. Imanati, J. Air Pollut. Control Assoc., 28 (1978) 350.

4 A. Vejux and P. Courtine, J. Solid State Chem., 23 (1978) 93.

5 H. Komiyama, T. Kanai and H. Inoue, Chem. Lett., (1984) 1283.

6 M.A. Drezdon, Inorg. Chem., 27 (1988) 4628.

7 T.J. Pinnavaia, T. Kwon and G.A. Tsigdinos, J. Am. Chem. Soc., 110 (1988) 3653.

8 G. Cao, M.E. Garcia, M. Alcala, L.F. Burgess and T.E. Mallouk, J. Am. Chem. Soc., 114 (1992) 7574.

9 F. Figueras, Catal. Rev. Sci. Eng., 30 (1988) 457.

10 T. Matsuda, M. Matsukata, E. Kikuchi and Y. Morita, Appl. Catal., 21 (1986) 297.

11 L.F. Nazar, S.W. Liblong and X.T. Yin, J. Am. Chem. Soc., 113 (1991) 5889.

12 S. Cheng and J.-T. Lin, in M. Occelli and H. Robson (Eds.), Expanded Clays and other Microporous Solids, Van Nostrand Reinhold, New York, NY, 1992, p. 170.
13 T.J. Pinnavaia and E.D. Dimotakis, Inorg. Chem., 29 (1990) 2394.

14 J. Twu and P.K. Dutta, J. Catal., 124 (1990) 503.

15 A. Clearfield and B.D. Roberts, Inorg. Chem., 27 (1988) 3237.

16 C. Ferragina, A. Frezza, A. La Ginestra, M.A. Massucci and P. Patrono, in M. Occelli and H. Robson (Eds.), Expanded Clays and other Microporous Solids, Van Nostrand Reinhold, New York, NY, 1992, p. 263.

17 S.-T. Wong and S. Cheng, Inorg. Chem., 31 (1992) 1165.

18 S. Cheng and T.-C. Wang, Inorg. Chem., 28 (1989) 1283.

19 M.W. Anderson and J. Klinowski, Inorg. Chem., 29 (1990) 3260 .

20 D.E.W. Vaughan, Catal. Today, 2 (1988) 187.

21 E. Stähli, Thesis, University of Bern, Bern, 1968.

22 H. Izawa, S. Kikkawa and M. Koizumi, J. Phys. Chem., 86 (1982) 5023.

23 H. Izawa, S. Kikkawa and M. Koizumi, Polyhedron, 2 (1983) 741.

24 G.J.J. Bartley, Catal. Today, 2 (1988) 233.

25 G. Johansson, Acta Chem. Scand., 14 (1960) 769, 771.

26 W.V. Rausch and H.D. Bale, J. Chem. Phys., 40 (1964) 3391.

27 H. Yoneyama and S. Haga, J. Phys. Chem., 93 (1989) 4833. 